\title{
Evaluation of Yield and Yield Components of Lowland Rice (Oryza sativa L.) Varieties in the Rainfed-Lowland Rice Producing Areas of Ethiopia
}

\author{
Zelalem Zewdu* Abebaw Dessie Mulugeta Atinaf \\ Fogera National Rice Research and Training Centre
}

\begin{abstract}
A field experiment was conducted to evaluate the performance of rice varieties for grain yield and other agronomic traits in the rainfed lowland rice producing areas of Ethiopia; Assosa, Bako, Pawe and Tepi during 2017 and 2018 cropping season. Six lowland rice varieties were included for evaluation and laid out in Randomized Complete Block Design with four replications.The combined analysis across years and locations revealed significant variations $(p \leq 0.001)$ among the tested varieties for days to heading, days to maturity, plant height, grain yield and thousand seed weight while non-significant difference was observed for number of filled grains per panicle and panicle length. Both location and year effects were highly significant for all measured traits. Variety by location and variety by year were highly significant $(p \leq 0.001)$ for days to heading, days to maturity, plant height, number of filled grains per panicle, and grain yield though variety by year was not significant for thousand seed weight. Variety by location and variety by year were non-significant for panicle length.Based on the performance of the variety in each test location and year, variety Ediget is recommended for Assosa $\left(2.93\right.$ tha $\left.^{-1}\right)$ and Bako (3.39 tha$\left.{ }^{1}\right)$ ) areas with days to heading and maturity ( 85 and 145 days) among the tested varieties, and variety Fogera- 2 $\left(5.19\right.$ tha $\left.^{-1}\right)$ for Pawe areas with maturity date (121 days) while, in Tepi area variety Hibir followed by Gumara are recommended for better productivity $\left(4.83\right.$ tha $^{-1}$ and 4.68 tha $\left.^{-1}\right)$ respectively. However, based on average grain yield over four locations and two years variety Ediget $\left(3.22\right.$ tha $\left.^{-1}\right)$ followed by Fogera-2 $\left(3.07\right.$ tha $\left.^{-1}\right)$ performed better than others and they are recommended for production.
\end{abstract}

Keywords: Lowland rice, Adaptation, Variety, Yield

DOI: $10.7176 / \mathrm{JNSR} / 9-24-02$

Publication date: December $31^{\text {st }} 2019$

\section{Introduction}

Rice production is a recent phenomenon in Ethiopia, as compared to other cereals crops. It had been introduced by in 1960s at Fogera and Gambela areas through North Korean and Dutch people respectively (CSA, 2011; Gebey et al., 2012).

The country has a huge potential of land for rice production in three ecosystems, upland (5.6 million ha), irrigated (3.7 million ha) and rain fed lowland. Now, a days the production and productivity of rice have been expanding throughout the country (MoARD, 2010). The production has been increased from 11,244.3 tons in 2007 to $126,806.4$ tons in 2016. Even though there is an increment in the production, the imports are also increasing from year to year. From 2008 to 2016 the imported rice had increased from 225,000 quintal to 3,118,270 quintal and causes more than 170 US dollars. This indicates the increasing demand of rice from year to year in the country. Rice is not only food securing crop but also a source of employment and income source for youths in most rice producing areas of the country (Dawit et al., 2018).

Even though there is huge potential and increasing demand of the crop, lack of high yielding varieties, terminal moisture stress and low soil fertility, disease and cold effect are the constraints that hinders the expansion and productivity of the crop (Abebaw, 2018). One of the major constraints in rice producing areas is lack of adaptable and high yielding improved rice varieties. So far eleven improved lowland rice varieties had been released in Ethiopia. However, cultivation of improved lowland varieties in most rice growing is limited, due to unavailability of adaptable rice varieties. Farmers grow old rice varieties venerable to disease and ends with low productivity. Therefore, this study was designed to select adapted and high yielding lowland rice varieties in the testing rice producing areas.

\section{Material and Methods}

The experiment was conducted at Assosa, Pawe, Bako and Tepi Research Centers during 2017 and 2018 cropping seasons in the rainfed lowland condition. The description of the trail site is indicated in Table 1. Five lowland rice varieties released from national and regional research centers and one widely produced rice varieties, but not yet registered (Table 2) were evaluated in a randomized complete block design replicated four times, on a plot size of 5 long $\times 1.5$ width. A spacing of $25 \mathrm{~cm}, 50$ and $1.5 \mathrm{~m} \mathrm{~cm}$ were used between rows, between plots and between blocks respectively.

Data were recorded on 5 randomly selected plants from the middle four rows for panicle length, plant height, 
number of filled grains per panicle, and on plot bases for days for heading, days for maturity. Grain yield and thousand seed weight were taken on plot basis from the four harvestable rows. Fertilizer application and weeding were carried out following the recommended packages. Data were subjected to analysis of variance (ANOVA) using GenStat version 12 edition software package (Payne et al., 2009).

Table 1. Description of experimental locations

\begin{tabular}{|c|c|c|c|c|c|c|c|}
\hline \multirow[t]{2}{*}{ Location } & \multirow{2}{*}{$\begin{array}{l}\text { Elevation } \\
(\mathrm{m})\end{array}$} & \multirow[t]{2}{*}{ Latitude } & \multirow[t]{2}{*}{ Longitude } & \multirow{2}{*}{$\begin{array}{l}\text { Annual rain } \\
\text { fall (mm) }\end{array}$} & \multicolumn{2}{|c|}{$\begin{array}{l}\text { Mean temperature }{ }^{(o} \\
\text { C) }\end{array}$} & \multirow[t]{2}{*}{ Soil type } \\
\hline & & & & & Min & Max & \\
\hline Assosa & 1580 & $10^{\circ} 03^{\prime} \mathrm{N}$ & $34^{\circ} 59^{\prime} \mathrm{E}$ & 1,275 & $14^{\circ} \mathrm{C}$ & $39^{\circ} \mathrm{C}$ & Nitosols \\
\hline Bako & 1590 & $9^{\circ} 06^{\prime} \mathrm{N}$ & $37^{\circ} 09^{\prime} \mathrm{E}$ & 1,245 & $9^{\circ} \mathrm{C}$ & $34.4^{\circ} \mathrm{C}$ & Nitosol \\
\hline Pawe & 1120 & $11^{\circ} 19^{\prime} \mathrm{N}$ & $36^{\circ} 24^{\prime} \mathrm{E}$ & 1587 & $16.3^{\circ} \mathrm{C}$ & $32.6^{\circ} \mathrm{C}$ & Vertisols \\
\hline Tepi & 1200 & $7^{\circ} 3^{\prime} \mathrm{N}$ & $35^{\circ} 18^{\prime} \mathrm{E}$ & 1522.1 & $15^{\circ} \mathrm{C}$ & $30^{\circ} \mathrm{C}$ & Nitosols \\
\hline
\end{tabular}

Sources (Tefera et al., 2017, Hailemariam et al., 2017)

Table 2. Description of experimental materials used for the study

\begin{tabular}{llllllll}
\hline Varieties & Released & Region & $\begin{array}{l}\text { Year of } \\
\text { released }\end{array}$ & $\begin{array}{c}\text { Altitude } \\
(\text { m.a.s.l })\end{array}$ & $\begin{array}{c}\text { Rain fall } \\
(\mathrm{mm})\end{array}$ & \multicolumn{2}{c}{ Productivity $\left(\mathrm{kg} \mathrm{ha}^{-1}\right)$} \\
\cline { 7 - 8 } & Center & & On-farm & On-station \\
\hline Ediget & Adet RC & Amhara & 2011 & $1150-1850$ & $800-1400$ & 32 & 52 \\
Hiber & Adet RC & Amhara & 2013 & $1150-1850$ & $1000-1400$ & $26-36$ & $34-47$ \\
Gumera & Adet RC & Amhara & 1999 & $1740-1900$ & 1520 & 30 & 38 \\
Fogera-2 & FNRRTC & Amhara & 2016 & $500-1590$ & $1000-1450$ & $37-49$ & $42-61$ \\
\hline
\end{tabular}

Demoze*

X-Jigna*

*Demoze and X-jigna have not yet registered, but they are under production in lowland rice producing areas.

\section{Result and Discussion}

The analysis of variance over years at Assosa showed highly significant difference $(p \leq 0.01)$ among varieties for days to maturity, plant height, number of filled grains per panicle, grain yield and thousand seed weight but not on panicle length (Table 3$)$. The effect of year was highly significant $(p \leq 0.01)$ on days to maturity, number of filled grains per panicle and thousand seed weight and significantly for panicle length at $(p \leq 0.01)$, and it was nonsignificant on plant height and grain. The interaction effect of year by variety showed highly significant difference $(p \leq 0.01)$ for number of filled grains per panicle, grain yield and thousand seed weight and days to maturity $(p \leq 0.05)$; while it was non-significant for panicle length and plant height. A similar finding was also reported by Hailemariam et al. 2017.

The average days to maturity ranged from 93 to 115 days; the variety Ediget matured earlier than the others while Fogera-2 was matured latter than the others. The varieties had minimum mean differences for panicle length. The average plant height was ranged from $80.6 \mathrm{~cm}$ to $98.6 \mathrm{~cm}$; Fogera-2 has the shortest plant height and Demoze has longest height among the tested varieties. A maximum filled grain was recorded on X-jigna (105.6), and small amount of filled grain was obtained on Gumara (80.9). The average grain yield was ranged from $2933 \mathrm{~kg}$ ha- 1 for Ediget to $2065 \mathrm{~kg}$ ha-1 for X-Jigna. The highest thousand seed weight was obtained for Hibir $(38.7 \mathrm{~g})$ followed by Gumara (37.0 g). The results revealed that Ediget $\left(2933 \mathrm{~kg} \mathrm{ha}^{-1}\right)$ and Demoze $\left(2933 \mathrm{~kg} \mathrm{ha}^{-1}\right)$ are the high yielder and well adapted varieties in the rainfed lowland rice producing areas of Assosa. The variety Ediget was the highest yielder followed by Demoze for Assosa areas and could be recommended for production. Hailemariam et al. 2017 had also reported the same result which confirmed that variety Ediget is the less responsive across different years and stable genotype in the area. 
Table 3. Mean performance of grain yield and yield related traits of six lowland rice varieties evaluated in 2017 \& 2018 cropping season at Assosa, Ethiopia.

\begin{tabular}{lcccccc}
\hline Variety & DM & PL & PH & FGPP & GY & TSW \\
\hline Ediget & 93 & 20.0 & 95.1 & 89.9 & 2933.0 & 36.6 \\
Hiber & 95 & 19.7 & 89.5 & 82.7 & 2124.0 & 38.7 \\
Demoze & 97 & 20.0 & 98.6 & 101.3 & 2457.0 & 31.2 \\
Gumera & 98 & 21.2 & 96.0 & 80.9 & 2162.0 & 37.0 \\
X-Jigna & 99 & 20.6 & 95.4 & 105.6 & 2065.0 & 31.2 \\
Fogera-2 & 115 & 19.9 & 80.6 & 101.3 & 2069.0 & 23.9 \\
\hline Mean & 100 & 20.2 & 92.5 & 93.6 & 2301.6 & 33.1 \\
CV (\%) & 2.2 & 9.4 & 9.3 & 17.1 & 21.8 & 7.1 \\
LSD (5 \%) & 3.163 & 2.8 & 12.3 & 23.1 & 722.4 & 3.4 \\
Variety (V) & $* * *$ & NS & $* * *$ & $* * *$ & $* * *$ & $* * *$ \\
Year (Y) & $* * *$ & $* *$ & NS & $* * *$ & NS & $* * *$ \\
VxY & $*$ & NS & NS & $* * *$ & $* * *$ & $* * *$
\end{tabular}

$\mathrm{DM}=$ Days to maturity, $\mathrm{PL}=$ Panicle length $(\mathrm{cm}), \mathrm{PH}=\mathrm{Plant}$ height $(\mathrm{cm}) \mathrm{FGPP}=$ Number of filled grains per panicle, $\mathrm{GY}=$, Grain yield (kg ha-1), TSW=Thousand seed weight $(\mathrm{g}), * * *, * * *$, and NS denotes significance difference at $p \leq 0.05, p \leq 0.01$ and $p \leq 0.001$ and non-significant difference respectively

The combined analysis of variance across years at Bako (Table 4) showed highly significant difference $(p \leq 0.01)$ among the tested varieties for days to maturity, days to heading, panicle length, plant height, number of filled grains per panicle, grain yield and thousand seed weight. The effect of year was highly significant $(p \leq 0.01)$ for days to maturity, days to heading, plant height, number of filled grains per panicle, grain yield, while it was non-significant on panicle length and thousand seed weight. The interaction effect of variety by year showed highly significant difference $(p \leq 0.01)$ for all measured traits (days to maturity, days to heading, panicle length, plant height, number of filled grains per panicle, grain yield) except for thousand seed weight.

Days to heading was ranged from 84 to 101 days; Edidet gave head earlier than the others, whereas Fogera1 was the late heading variety. Ediget was the earliest maturing (145 days) and Fogera-2 (153 days) was the late maturing among the tested varieties. The average panicle length was ranged from $19.7 \mathrm{~cm}$ to $22.4 \mathrm{~cm}$, shortest panicle length recorded for Demoze and longest was for Gumara. The highest plant height was recorded for Demoze $(127.9 \mathrm{~cm})$ followed by X-jigna (125.4) whereas the shortest plant height was obtained for Fogera-2 (104.2). The number of filled grains per panicle ranged from 30.5 (Fogera-2) to 55.1 (Ediget). Thousand seed weight was highest for variety Ediget (30.4) and Hiber (30.4), while the small grain weight was obtained for Fogera-2 (18.9). Regarding the grain yield, Ediget was the higher yielder followed by Hiber and the two varieties could be recommended for production in Bako areas.

Table 4. Mean performance of grain yield and yield related traits of six lowland rice varieties evaluated in 2017 \& 2018 cropping season at Bako, Ethiopia

\begin{tabular}{lccccccc}
\hline Variety & DH & DM & PL & PH & FGPP & GY & TSW \\
\hline Ediget & 85 & 145 & 20.3 & 114.1 & 55.1 & 3398.0 & 30.4 \\
Hiber & 84 & 146 & 20.1 & 107.1 & 54.0 & 2820.0 & 30.3 \\
Demoze & 88 & 145 & 19.7 & 127.9 & 44.2 & 2637.0 & 26.3 \\
Gumera & 94 & 145 & 22.4 & 122.8 & 33.1 & 1847.0 & 26.9 \\
X-Jigna & 89 & 146 & 20.6 & 125.4 & 35.8 & 1440.0 & 26.6 \\
Fogera-2 & 101 & 153 & 19.8 & 104.2 & 30.5 & 1419.0 & 18.9 \\
\hline Mean & 90 & 147 & 20.5 & 116.9 & 42.0 & 2260.1 & 26.6 \\
CV (\%) & 2.6 & 1.1 & 4.7 & 3 & 25.4 & 36.9 & 11.6 \\
LSD (5 \%) & 2 & 2 & 1.0 & 3.6 & 10.9 & 847.4 & 3.1 \\
Variety (V) & $* * *$ & $* * *$ & $* * *$ & $* * *$ & $* * *$ & $* * *$ & $* * *$ \\
Year (Y) & $* * *$ & $* * *$ & NS & $* * *$ & $* * *$ & $* * *$ & NS \\
VxY & $* * *$ & $* * *$ & $* * *$ & $* * *$ & $* * *$ & $* * *$ & NS \\
\hline
\end{tabular}

$\mathrm{DH}=$ Days to heading, $\mathrm{DM}=$ Days to maturity, $\mathrm{PL}=$ Panicle length $(\mathrm{cm}), \mathrm{PH}=\mathrm{Plant}$ height $(\mathrm{cm}) \mathrm{FGPP}=\mathrm{Number}$ of filled grains per panicle, GY=, Grain yield (kg ha-1), TSW=Thousand seed weight (g), *** denotes significance difference at $p \leq 0.001, \mathrm{NS}=$ Non-significant difference

The combined analysis of variance across years at Pawe (Table 5) showed highly significant difference $(p \leq 0.01)$ for days to heading, days to maturity, plant height, number of filled grains per panicle, grain weight and thousand seed weight; and significant difference $(p \leq 0.05)$ was observed for panicle length among the tested varieties. The effect of year was also highly significant on all measured traits $(p \leq 0.01)$ except panicle length. The interaction of variety and year revealed a highly significant difference $(p \leq 0.01)$ for days to heading, days to maturity, plant height, whereas number of filled grains per panicle, grain yield and thousand seed weight didn't show significant difference. There was highly significant difference among varieties. The non-significant effect of 
year by variety indicates that the varieties are stable across years for the testing locations.

Variety Demoze (70 days) followed by Ediget (72 days) were the early variety for heading while Fogera-2 (121 days) was the late heading variety. Panicle length is one of the major yield contributing traits. The longest panicle was recorded on variety Gumara followed by Fogera- 2 while shortest panicle length was recorded on Hibir. The average plant height ranged from 85.6 (Hibir) to 107.2 (Gumara). The tallest variety were Gumara followed by Demoze and x-jigna, while the shortest height was recorded on Hibir and Fogera-2. Filled grain is one of the yields contributing factor and the highest filled grain and grain yield were recorded on the same variety Fogera-2 which were117.6 and $5188 \mathrm{~kg} \mathrm{ha}^{-1}$ and followed by Gumara 99.2 and $3619 \mathrm{~kg} \mathrm{ha}^{-1}$ respectively. However, the small number of filled grains was recorded on variety Hiber whereas Demoze was the lowest yielder variety. Thousand seed weight was higher for variety Hiber followed by Gumara while the smaller was recorded on Fogera2 .

Table 5. Mean performance of grain yield and yield related traits of six lowland rice varieties evaluated in $2017 \&$ 2018 cropping season at Pawe, Ethiopia

\begin{tabular}{lccccccc}
\hline Variety & DH & DM & PL & PH & FGPP & GY & TSW \\
\hline Ediget & 72 & 106 & 18.2 & 89.2 & 95.6 & 2860.0 & 32.0 \\
Hiber & 68 & 102 & 17.7 & 85.6 & 81.7 & 2702.0 & 30.8 \\
Demoze & 70 & 106 & 18.1 & 95.4 & 83.0 & 2168.0 & 24.3 \\
Gumera & 79 & 115 & 19.8 & 107.2 & 99.2 & 3619.0 & 29.1 \\
X-Jigna & 69 & 104 & 18.8 & 95.8 & 89.2 & 2218.0 & 25.7 \\
Fogera-2 & 85 & 121 & 19.7 & 87.1 & 117.6 & 5188.0 & 20.9 \\
\hline Mean & 74 & 109 & 18.7 & 93.4 & 94.4 & 3125.6 & 27.1 \\
CV (\%) & 2.5 & 2.1 & 6.8 & 7.1 & 10.8 & 14.1 & 3.9 \\
LSD (5 \%) & 2 & 2 & 1.3 & 6.7 & 10.4 & 447.5 & 1.1 \\
Variety (V) & $* * *$ & $* * *$ & $* *$ & $* * *$ & $* * *$ & $* * *$ & $* * *$ \\
Year (Y) & $* * *$ & $* * *$ & NS & $* * *$ & $* * *$ & $* * *$ & $* * *$ \\
VxY & $* * *$ & $* * *$ & NS & $* * *$ & NS & NS & NS \\
\hline
\end{tabular}

$\mathrm{DH}=$ Days to heading, $\mathrm{DM}=$ Days to maturity, $\mathrm{PL}=$ Panicle length $(\mathrm{cm}), \mathrm{PH}=\mathrm{Plant}$ height $(\mathrm{cm}) \mathrm{FGPP}=\mathrm{Number}$ of filled grains per panicle, GY=, Grain yield (kg ha-1), TSW=Thousand seed weight ( $\mathrm{g}$ ), ** and *** denotes significance difference at $p \leq 0.01$ and $p \leq 0.001$ respectively, NS=Non-significant difference

The analysis of variance at Tepi revealed that the varieties were highly significant different $(p \leq 0.01)$ for days to heading days to maturity, plant height, number of filled grains per panicle, grain yield and thousand seed weight while panicle length didn't show significant difference in 2017 cropping season (Table 6). A similar result was also previously reported by Tefera et al., 2017. The average days to heading for the varieties in this cropping season was 92 days. The variety which took long days to head was Fogera-2 (108 days), while variety Ediget and Demoze (87 days) followed by Hiber (88 days) are earlier to head. Days to maturity ranged from 118 to 137 days, the early maturing variety was Ediget while Fogera-2 (137 days) was the late maturing variety in the area. The longest panicle length and tallest plant height was recorded on Gumara $19.7 \mathrm{~cm}$ and $111.1 \mathrm{~cm}$ respectively. Gumara was also the best yielding variety (4680 kg ha-1) followed by Hibir (4830 kg ha-1) whereas Demoze (2398 kg ha${ }^{1}$ ) and $\mathrm{X}$-jigna was the lower yielder varieties in the area. The higher thousand seed weight were also obtained on those high yielding varieties, Hibir (35.8 g) and Gumara $35.8 \mathrm{~g}$ ). As a result, Hiber followed by Gumara were the best variety in grain yield, filed grain and also thousand seed weight in the cropping season and area.

Table 6. Mean performance of grain yield and yield related traits of six lowland rice varieties evaluated in 2017 cropping season at Tepi, Ethiopia

\begin{tabular}{lccccccc}
\hline Variety & DH & DM & PL & PH & FGPP & GY & TSW \\
\hline Ediget & 87 & 118 & 18.6 & 108.3 & 77.1 & 4173.0 & 34.8 \\
Hiber & 88 & 128 & 18.4 & 99.5 & 78.1 & 4830.0 & 35.8 \\
Demoze & 87 & 129 & 18.8 & 99.6 & 55.7 & 2398.0 & 28.3 \\
Gumera & 93 & 130 & 19.7 & 111.1 & 75.4 & 4680.0 & 35.8 \\
X-Jigna & 91 & 131 & 19.1 & 101.9 & 67.4 & 2784.0 & 29.2 \\
Fogera-2 & 108 & 137 & 19.1 & 79.6 & 66.3 & 4163.0 & 20.2 \\
\hline Mean & 92 & 129 & 18.9 & 100.0 & 70.0 & 3837.9 & 30.6 \\
CV (\%) & 4.3 & 1.8 & 5.9 & 6.7 & 14.5 & 22.8 & 12.2 \\
LSD (5 \%) & 5.9 & 3.5 & 1.7 & 10.0 & 15.3 & 1316.9 & 5.6 \\
Variety (V) & $* * *$ & $* * *$ & NS & $* * *$ & $* * *$ & $* * *$ & $* * *$ \\
\hline
\end{tabular}

$\mathrm{DH}=$ Days to heading, $\mathrm{DM}=$ Days to maturity, $\mathrm{PL}=$ Panicle length $(\mathrm{cm}), \mathrm{PH}=\mathrm{Plant}$ height $(\mathrm{cm}) \mathrm{FGPP}=\mathrm{Number}$ of filled grains per panicle, GY=, Grain yield (kg ha-1), TSW=Thousand seed weight (g), *** and NS denotes significance difference at $p \leq 0.001$ and non-significant difference respectively

Combined analysis of variance was performed to assess the performance of varieties with the test locations and years. Significant variation $(p \leq 0.001)$ was observed among the tested varieties for days to heading, days to 
maturity, panicle length, plant height, grain yield and thousand seed weight while non-significant difference was observed for number of filled grains per panicle (Table 7). Both location and year effects were highly significant for all measured traits indicating the test locations and years differed. Variety by location and variety by year were highly significant $(p \leq 0.001)$ for days to heading, days to maturity, plant height, number of filled grains per panicle, and grain yield indicating that varieties performed differently in each location and year. Though variety by year was not significant for thousand seed weight. Variety by location and variety by year were non-significant for panicle length and suggesting that the stability of the varieties across loactions and years. The interaction of variety by location by year was highly significant for days of heading, days of maturity, plant height, grain yield and thousand seed weight while panicle length and number of filled grains per panicle were not significant for this interaction.

Grain yield is the most important economic trait in most crop improvement programs. The highest grain yield was recorded for Ediget (3222 kg ha-1) and Fogera-2 (3073 kg ha-1) while the low grain yield was recorded on XJigna. This is due to the long age of the variety under production. The average maturity days for the variety was 88 days; Fogera-2 and Gumara were the late maturing varieties and Hiber and Ediget were early maturing. Variety Fogera-2 had high number of filled grains per panicle and grain yield. However, variety Ediget was the best variety across locations and year interms of number of filled grains per panicle and grain yield per ha $\left(3222 \mathrm{~kg} \mathrm{ha}^{-1}\right)$ with high thousand seed weight.

Table 7. Combined analysis of mean performance of grain yield and yield related traits of six lowland rice varieties over locations and years

\begin{tabular}{lccccccc}
\hline Variety & DH & DM & PL & PH & FGPP & GY & TSW \\
\hline Ediget & 84 & 131 & 19.4 & 100.8 & 83.1 & 3222.0 & 33.2 \\
Hiber & 83 & 133 & 19.0 & 94.8 & 73.5 & 2875.0 & 33.7 \\
Demoze & 86 & 134 & 19.2 & 106.2 & 74.0 & 2417.0 & 27.4 \\
Gumera & 91 & 136 & 20.9 & 109.0 & 75.9 & 2848.0 & 31.7 \\
X-Jigna & 86 & 133 & 19.9 & 105.0 & 76.5 & 2033.0 & 28.0 \\
Fogera-2 & 101 & 143 & 19.7 & 89.1 & 81.6 & 3073.0 & 21.1 \\
\hline Mean & 88 & 135 & 19.7 & 100.8 & 77.4 & 2744.6 & 29.2 \\
CV (\%) & 2.9 & 1.5 & 7.2 & 6.5 & 26.7 & 25.8 & 8.8 \\
Variety (V) & $* * *$ & $* * *$ & $* * *$ & $* * *$ & NS & $* * *$ & $* * *$ \\
Location & $* * *$ & $* * *$ & $* * *$ & $* * *$ & $* * *$ & $* * *$ & $* * *$ \\
Year & $* * *$ & $* * *$ & $* * *$ & $* * *$ & $* *$ & $* * *$ & $* * *$ \\
VxL & $* * *$ & $* * *$ & $\mathrm{NS}$ & $* * *$ & $* *$ & $* * *$ & $* *$ \\
VxY & $* * *$ & $* * *$ & $\mathrm{NS}$ & $* * *$ & $* *$ & $* * *$ & NS \\
LxY & $* * *$ & $* * *$ & $*$ & $* * *$ & $* *$ & $* * *$ & $* * *$ \\
VxLxY & $* * *$ & $* * *$ & $\mathrm{NS}$ & $* * *$ & $\mathrm{NS}$ & $* * *$ & $* * *$ \\
\hline DH Days & & $* * *$ &
\end{tabular}

$\mathrm{DH}=$ Days to heading, DM=Days to maturity, $\mathrm{PL}=$ Panicle length $(\mathrm{cm}), \mathrm{PH}=\mathrm{Plant}$ height $(\mathrm{cm}) \mathrm{FGPP}=\mathrm{Number}$ of filled grains per panicle, $\mathrm{GY}=$, Grain yield $\left(\mathrm{kg} \mathrm{ha}^{-1}\right)$, TSW=Thousand seed weight $(\mathrm{g}), *$, **, *** and NS denotes significance difference at $p \leq 0.05, p \leq 0.01, p \leq 0.001$ and non-significant difference respectively

An "ideal" genotype is one that has both high mean yield capacity and high stability. The center of concentric circles (Figure 1) represents the position of an "ideal" genotype, which is defined by a projection onto the meanenvironment axis that equals the longest vector of the genotypes that had above-average mean yields and by a zero projection onto the perpendicular line (zero variability across all environments). The closer a genotype to the ideal one is the more valuable it is.

Although such an "ideal" genotype may not exist in reality, it can be used as a reference for genotype evaluation (Yan, Tinker, 2006). The ranking based on the genotype-focused scaling assumes that stability and mean yield are equally important. Thus variety-1 (Ediget), variety-2 (Hibir) are located near to the concentric circle are also regarded as valuable genotypes in terms of yield capacity and stability. 


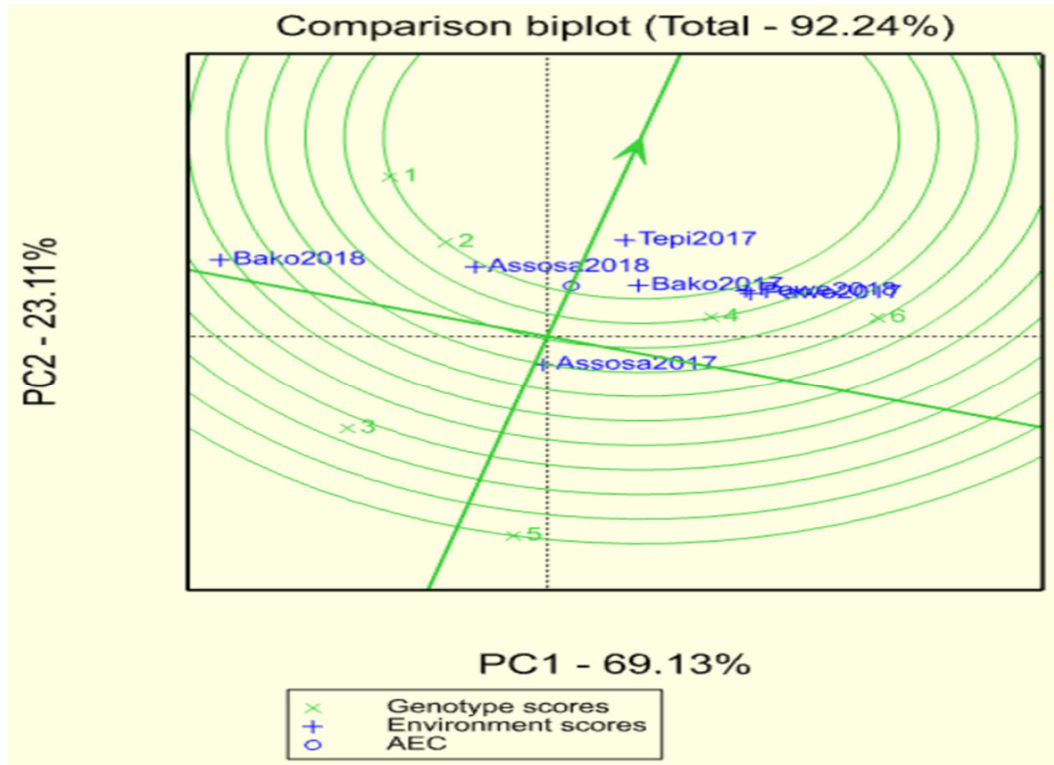

Figure 1. The average-environment coordination (AEC) view of ranking rice lowland rice varieties relative to an ideal genotype (center of the concentric circle).

\section{Conclusion and Recommendation}

The combined analysis of variance over years and locations showed that there were high interactions of variety by location, variety by year and variety by location by year. This indicated that varieties performance varies in each location and year. Therefore, the variety Ediget had best performance in Bako and Assosa and it is recommended for production in the areas. While Fogera-2 had better performance in Pawe and is recommended for production in the area. In Tepi area variety Hibir and Gumara followed by Ediget had better performance and they are recommended for production. However, the combined the combined analysis over years and locations indicated that variety Ediget had better performance and it is recommended for early maturity and good yield followed by Fogera-2 for good yield and late maturity.

\section{Acknowledgments}

The first authors are thankful to Ethiopian Institute of Agricultural Research through Fogera national rice research and training center for financial support. In addition to this, Assosa, Pawe, Bako and Tepi research centers are highly acknowledged for executing the experiment with great responsibility.

\section{References}

Abebaw Dessie (2018). Cereal crops research achievements and challenges in Ethiopia International Journal of Research \& Review (www.ijrrjournal.com) Vol.5; Issue: 9; September 2018.

Tefera A, Alamerew S, Tulu L (2017). Genetic variability, heritability and genetic advance for Yield and its Related Traits in Rainfed Lowland Rice (Oryza sativa L.) Genotypes at Fogera and Pawe, Ethiopia. Adv Crop Sci Tech 5: 272. doi: 10.4172/2329-8863.1000272

Central Statistical Agency (2011). Report on area and production of major crops (Private Peasant Holdings, Meher Season). Addis Ababa, Ethiopia.

Dawit A, Agajie T, Abebaw A, Degu A, Tilahun T, and John T (2018). A historical analysis of rice commercialization in Ethiopia: the case of the Fogera plain. A blog posted in future agricultures consortium website. Posted on May 31, 2018. Link: https://www.future-agricultures.org/blog/from-the-fogera-plainhow-one-man-helped-to-build-a-regional-industry/

Gebey T, Berhe K, Hoekstra D, and Bogale A (2012). Rice value chain development in Fogera woreda based on the IPMS experience. Nairobi, Kenya: ILRI. 23pp.

Hailemariam S, Taddesse L, Abebaw D (2017). GGE Biplot analysis of yield stability in multi-season trials of early matured rice $(O$. Sativa) genotypes in rain fed lowland ecosystem

Ministry of Agriculture and Rural Development (MoARD) (2010). National rice research and development strategy of ethiopia. Addis Ababa, Ethiopia, pp. 48.

Payne RW, Murray DA, Harding SA, Baird DB, Soutar DM (2009). An introduction to GenStat for Windows (12th edition). VSN International, 5 the Waterhouse, Waterhouse Street, Hemel Hemstead, UK.

Yan W, Tinker NA (2006). Biplot analysis of multi-environment trial data: principles and applications. Canadian Journal of Plant Science, 86: 623-645 